\title{
REPRESENTATION WITHOUT TAXATION, TAXATION WITHOUT CONSENT: THE LEGACY OF SPANISH COLONIALISM IN AMERICA*
}

\author{
ALEJANDRA IRIGOIN \\ London School of Economics ${ }^{\mathrm{a}}$
}

\begin{abstract}
The essay examines Spain's colonial legacy in the long-run development of Spanish America. It surveys the fiscal and constitutional outcomes of independence and assesses the relative burden imposed by colonialism. Constitutional asymmetries between revenue collecting and spending agents constrained de facto governments' power to tax. Inherent disparities embedded in the colonial fiscal system worsened with vaguely defined representation for subjects and territories and vexed their aggregation into a modern representative polity. Governments with limited fiscal capacity failed to deliver public goods and to distribute the costs and benefits of independence equitably. Growing indirect taxes, debt and money creation allowed them to transfer the fiscal burden to other constituents or future generations. Taxpayers became aware of the asymmetry between private contributions and public goods and hence favoured a low but regressive taxation. Comparisons with trajectories in the metropolis and the United States are offered to qualify this legacy.
\end{abstract}

Keywords: colonial legacy, institutions, long-run development, Spanish America

JEL Codes: N1, N16, N2, N20, N4, N40

* Received 8 July 2015. Accepted 15 December 2015. The author thanks to Leticia Arroyo Abad and Bartolome Yun Casalilla for their generous comments and suggestions. All errors remain the author's own.

a Department of Economic History, London School of Economics, Houghton St, London WC2A 2AE, UK. m.a.irigoin@lse.ac.uk 


\section{RESUMEN}

El articulo examina el «legado» del colonialismo español en el desarrollo de Hispanoamérica en el largo plazo. Discute el resultado fiscal y constitucional de la Independencia y estima la carga de la extracción relativa impuesta por el fisco colonial. Asimetrías constitucionales en los agentes que recaudaban impuestos y ejecutaban el gasto limitó de facto la capacidad fiscal de los gobiernos. Disparidades inherentes al propio sistema fiscal colonial agravaron esta poca capacidad con una representación política de súbditos/ciudadanos y territorios ambigua que problematizó su agregación posteriormente en un sistema político independiente cabalmente representativo. Gobiernos con capacidad fiscal limitada fracasaron en la provisión de bienes públicos y en la distribución equitativa de los costos y los beneficios de la independencia. Impuestos indirectos crecientes, deuda y creación de dinero permitieron a los gobiernos transferir el peso fiscal a otros sujetos políticos que los propios o a futuras generaciones. Los contribuyentes entendieron estas asimetrías entre contribuciones privadas y bienes públicos de modo de que favorecieron una baja pero regresiva fiscalidad. La comparación con la trayectoria fiscal de la ex - metrópolis y los Estados Unidos permiten ofrecer una calificación de este legado colonial.

Palabras clave: legado colonial, instituciones, desarrollo en el largo plazo, América hispana

\section{INTRODUCTION}

This paper takes issue with institutionalist models to discuss the notion of colonial legacy in setting the development path of Latin America ${ }^{1}$, delving into the history of colonial Spanish America and searching for another possible set of institutions, which might well explain Latin America's economic development. It builds on previous research on the political economy, taxation and governance of the Spanish Empire and echoes other assessments of the region's economic performance in the post-independence period. Thus, it revisits the notion of Spanish colonialism current in the institutionalist literature. Following their rationale it addresses the question of why, if colonial rule was so prejudicial for development, independence did not change that path. It also investigates the extent to which this is a history of bad colonialism if it was the case that the metropolis suffered badly from the same malaise - for most of the $19^{\text {th }}$ century at least - and to what extent

1 Broadly, this refers to well-known research by Acemoğlu, Johnson and Robinson and Engerman and Sokoloff (various dates). 
fundamentals of the colonial political economy remained in place after the end of Spanish rule. In so doing, an analytical argument is offered on the channels and mechanisms of persistence; one of the main aspects of the institutionalist interpretation.

Section 2 briefly describes the governance, the economic basis and workings of the colonial state that permitted the territorial expansion of the empire and organised the economy under its control. Section 3 discusses the exogenous shock resulting from the Napoleonic occupation of Spain in 1808, which inflicted a fatal blow for the continuation of the rule and triggered major reforms in both Spain and in the colonies on its wake. It discusses interpretations of the colonial fiscal burden - and its release - as the legacy of independence. Section 4 offers some first estimates of the subsequent fiscal burden and surveys the institutional changes affecting taxation and representation, which transformed the political fundamentals of Spanish rule. Focussing on the changes initiated with the Cadiz constitution of 1812, it compares fiscal and financial developments in the colonies and the metropolis to point out the debatable nature of a colonial legacy as both suffered very similar problems - and sought very similar solutions. Section 5 analyses institutions of taxation and political representation in the United States before and after the Revolution to highlight the differences in fiscal and political matters with Spanish America - making the United States a problematic yardstick to assess the institutional determinants of long-run development comparatively. The paper concludes with another institutional argument - different from the colonial origins - pointing at another type of legacy that shaped the long-run economic performance of Spain and her former colonies; that is, the inconsistency between taxation and representation in the constitutional setting implemented in the $19^{\text {th }}$ century, which ultimately engendered persistent macroeconomic instability with detrimental consequences visible to date.

\section{SPANISH COLONIALISM}

A cursory characterisation of the economy in this section qualifies some claims made concerning the nature of Spanish colonialism. As shown elsewhere, the governance that Spain established in the New World relied heavily on the local agency of co-opted subjects, individuals and corporate. The economic structure organised by Spaniards relied on a disproportionately high land/labour ratio exacerbated by the collapse of the native population in the $16^{\text {th }}$ century, a demographic shortfall roughly three times more dramatic than the one caused by the Black Death. The population took more than two centuries to rebound to pre-conquest levels as recovery was constantly held back by epidemics. By 1800 , the population of frontier regions such as Northern Mexico, Chile, Venezuela and the River 
Plate was increasing more quickly as these were the fastest-growing regions at the time together with Cuba - which, thanks to African labour, constituted another dynamic frontier in the empire.

A great deal of local autonomy in the governance of colonial cities and villages replicated Spain's institutional order and structure of representation found in her pueblos and towns (Quijada 2008). Citizenry was local and the commonwealth organised in a corporate order led by local notables. Spanish rule relied on overlapping and competing authorities, secular and religious, administrative and judicial, locally appointed (or purchased) and confirmed by the king, which checked each other out. The constant bargaining between bodies and individuals, that is, the governor and the bishop, the bishop and the religious orders, the governor and the courts (audiencias), made the king in Spain Hispaniarum et Indiarum Rex the authority of last resort; he conceded legality to contracts and was the ultimate arbiter in disputes between subjects, cities/towns and corporations ${ }^{2}$. By incorporating traditional institutions of authority and conflict resolution indigenous people or pueblos (lit. towns) enjoyed equal status to Europeans before the king though were separated by their own judicial freedoms. As the ecclesiastics, the military, the guilds of merchants and miners, the indigenous pueblos enjoyed judicial and fiscal privileges (fueros, aforamientos) and were thus unequal before the treasury ${ }^{3}$. This did not make the colonial society more equal; it is simply that distinctions were not purely established by colour.

By the mid- $18^{\text {th }}$ century, taxes on external and domestic trade provided most fiscal revenues. Mining as such was never the main source of royal income as it was a private venture and the burden from direct royal taxes was somewhat offset by the royal subsidies on quicksilver (Grafe and Irigoin 2006). A significant amount of revenue was redistributed within the territory to settlements both near and far such as Cuba, California, Concepcion and Manila. This provided working capital for new economic activities and attracted trade to the ports; it financed the expansion of the empire and sustained the growth of existing cities and of the private mining enterprise. Unlike other European empires, this was a self — and abundantly — financed economy, which had continued expanding over the territory since early in the $16^{\text {th }}$ century.

Elsewhere, this state has been characterised as «developmentalist» as it was deeply embedded in the local economy and originated significant redistributive effects in its expansion (Grafe and Irigoin 2012); central or metropolitan control was rather limited as was its rate of fiscal extraction to Spain. Revenues broadly defined as «from the Indies» never accounted for

\footnotetext{
2 From Latin arbiter, judge, supreme ruler in use in Medieval France and England.

3 Unlike the situation in the United States, being black did not necessarily mean being a slave and the first minority everywhere was free people of mixed races. These features challenge the triple colour division of the colonial population in Sokoloff and Engerman (2000, table 3).
} 
FIGURE 1

\section{CONTRIBUTION FROM THE INDIES TO THE SPANISH TREASURY AND TOTAL AND NET REVENUES IN MAINLAND AMERICA — IN THOUSANDS OF SILVER PESOS}

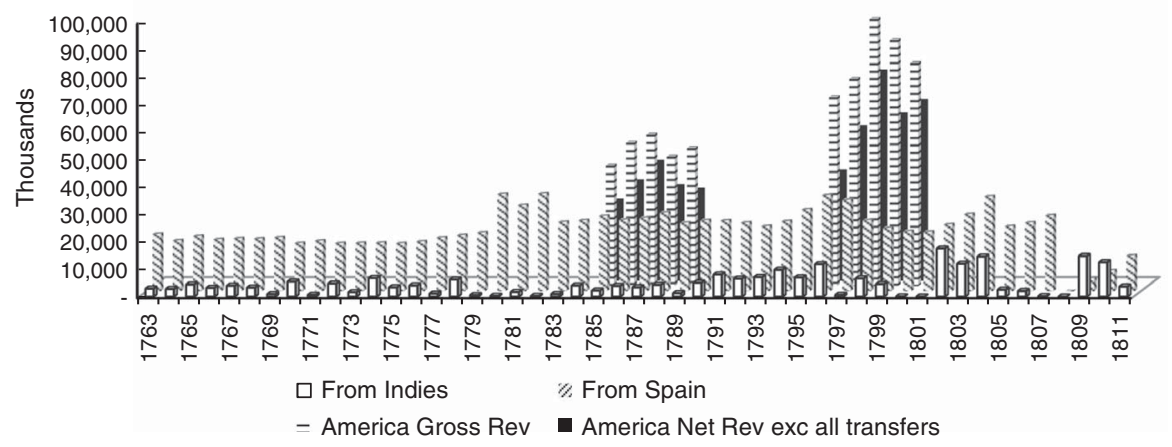

Note: Conversion rate between reals de vellon and the Spanish American silver peso was 20:1 as indicated by Marichal.

Sources: Data «from Indies» and «from Spain» (Marichal 2008, table 1.1, appendix); America gross and net revenues from Grafe and Irigoin (2006, 2012, table 1).

more than a fifth of metropolitan revenues in the $18^{\text {th }}$ century. Yet, these amounts pale when compared with the money collected in the empire, as shown in Figure 1. The proportion directly appropriated by the Spanish king represented a few percentage points of the revenue generated in the colonies. Only the lack of a comparison of relative values could give the impression that there was any sizable «extraction» of revenues. Such was the wealth of the Spanish American economy.

Colonial administration was in private hands; extended sale of office plus tax collection and spending outsourced to merchants or miners' guilds, local priests, and tax farmers all resulted in the near privatisation of fiscal functions on the one hand, and the supply of public goods by the church on the other, all of which placed a significant amount of control of the state business in local hands. Little European migration went directly to newer remote areas; rather old settlements were the springboards from which population and capital were raised to move further inland. This Smithian type of growth expanded the private economic activities engaged in the production and trade of natural resource-intensive goods. In so doing, the colonial state was also expanding its fiscal base with the progressive creation of treasury districts. Unlike the process of aggregation or mergers in the European (and United States) path to state formation, revenue collection points multiplied over time in Spanish America. This process accelerated in the $18^{\text {th }}$ century with population growth - hence the fiscal subdivision of Mexico and the River Plate - a feature that qualifies the notion of the 
Bourbons' greater centralisation. Spending was also controlled by locals as imperial defence was organised and run by locally organised militias (Grafe and Irigoin 2012).

The extraction by the colonial state should not be equated to the economic exploitation that Spaniards imposed on the New World; Spanish colonialism was indeed a highly private enterprise, locally run and heavily subsidised by the colonial treasury. Since the early $16^{\text {th }}$ century, the bulk of the specie sent to Spain was made up of private treasure, for example, «emigrants» remittances, savings of passengers and the bulk of it from the balance of trade' (Hamilton 1929, p. 463). The proportion increased together with more mining and trade. No chartered company was established to trade with America in the fashion of the other European companies - until very late and to little effect ${ }^{4}$, no monopoly exploited the production of silver within or its export outside America; the single direct royal stake in the mining economy was the provision of quicksilver crucial for the amalgamation of silver; nor had capital to be raised in the metropolis to establish a viable economic profit in the colonies - unlike most other European imperial ventures as pointed out by Adam Smith. Indeed, this was a very different political economy from that conceived by institutionalists.

By the 1800s, such a system of internal distribution of revenues was assisting the fast-growing new regions. As pointed out by Summerhill (2008), fiscal transferences did increase output because revenues were flowing from lower productivity areas to areas with potentially higher productivity as was the case of Cuba and the River Plate. Throughout, exports diversified beyond silver towards more land-intensive commodities like wheat, copper, indigo, cochineal, tobacco, sugar, cacao and hides; and population - particularly in urban areas - was growing fast ${ }^{5}$. Customs yields in both colonies, for instance, increased tenfold between 1778 and 1805, and this should be considered a lowest bound for growth of commerce as trade with «neutrals» and contraband was the norm. Both colonies «per capita GDP in 1800 was higher than the US» (Coatsworth 1998) and higher than any other Spanish settlement at the time. It is a challenge to both endowments and institutional models to disentangle how colonies of the same empire with such a different set of endowments, free available land and low population in the temperate River Plate and tropical agriculture with slave labour in Cuba, could both stand out. Economic historians have adhered to the idea of trade openness,

4 The Casa de Contratación did not own ships; it was actually a shipping agency for the private fleet convoyed over the Atlantic. The Real Compañia de la Habana briefly enjoyed the monopoly of trade with Cuba from 1740 to 1790 , although its decline was noticeable as from 1763. A Basque trading company was chartered for the trade with Caracas in 1728 and was transformed into the Real Compañia de Filipinas in 1785. In 1776 trade at Caracas was liberalised.

5 Cuba's slave population grew at 3.7 per cent/year and its free population at 2 per cent between 1774 and 1792 (Grafe and Irigoin 2006, p. 259). Annual growth rates in Buenos Aires were, respectively, 1.8 per cent and 3.2 per cent (Johnson 1979). 
which somewhat characterised both export economies. Both, however, were also main recipients of large revenue transfers from other treasuries, which ought to lower the relative cost of capital locally. Maps show the relative importance of the intra-colonial transfers as proportion of net revenues in each fiscal district (Figures 2A and 2B).

When other European powers threatened the colonies in the 1760s investments for defence demanded a greater tax take from the economy; without a centralised administrative structure and scant control of its bureaucracy, further spending required the empire a greater state autonomy with which to extract more - that is, greater state capacity. In order to extract more, the metropolitan government had to gain control over collection from vested interests or find new sources ${ }^{6}$. It tried both. This is, in a nutshell, what the socalled Bourbon reforms sought and to which the establishment of monopolies was decisive. The extension of monopolies on price inelastic goods such as tobacco in the 1760s substantially increased revenues in districts such as Mexico, Puebla, Guanajuato, Havana, Manila, Santiago de Chile, Caracas, Santo Domingo and Quito. Start-up capital for the production and distribution of tobacco on an imperial scale originated in intra-colonial treasury transfers. This improvement, however, did not stop the dissipation of revenues into private hands. The running costs of Mexico's tobacco factory consumed more than 50 per cent of its income (Deans Smith 1992, p. 54).

Between 1730 and 1780, the number of fiscal districts doubled from thirtysix to seventy-one - at least in the region covered by TePaske and Klein's (1982) sample. An excise tax, the alcabala, was extended to products and taxpayers formerly exempted; the rate was increased too, but its collection remained farmed out to individuals and local corporations such as the Cabildo in Puebla or the Consulado in colonial capital cities. Constrained by the very (unwritten) constitutional structure and centuries of - in practice - limited government, imperial rivalries ironically pushed the Spanish king to greater dependence on his wealthy colonial subjects. Colonial treasuries borrowed heavily from local subjects - in various ways - particularly from the 1780 s (Marichal 2008; Grafe and Irigoin 2012; Grieco 2014). Marichal (2008) argues that colonials' contribution to metropolitan finances bankrupted the Mexican treasury. He is not conclusive, however, regarding the degree by which local vested interests might have profited from such «extraction». Under Charles III, treasuries extracted a larger amount of revenues but at the same time expenses increased even further. Even if they were only partly appropriated by colonial stakeholders the «reforms» brought locals substantial opportunities to cream off the newly expanded fiscal capacity. A rough calculation in Table 1 considering the partial nature of the data - shows the impressive growth of fiscal income and spending throughout the $18^{\text {th }}$ century.

6 As early as 1787 Carlos III felt hopeless about the resistance to the (failed) implementation of the 1749 Unica Contribución levy in Spain, cited in Fontana (1987, p. 2). 
FIGURE 2

(A) NEW SPAIN (1796-1800) AND (B) PERU, UPPER PERU, CHILE AND RIVER PLATE (1796-1800)

A
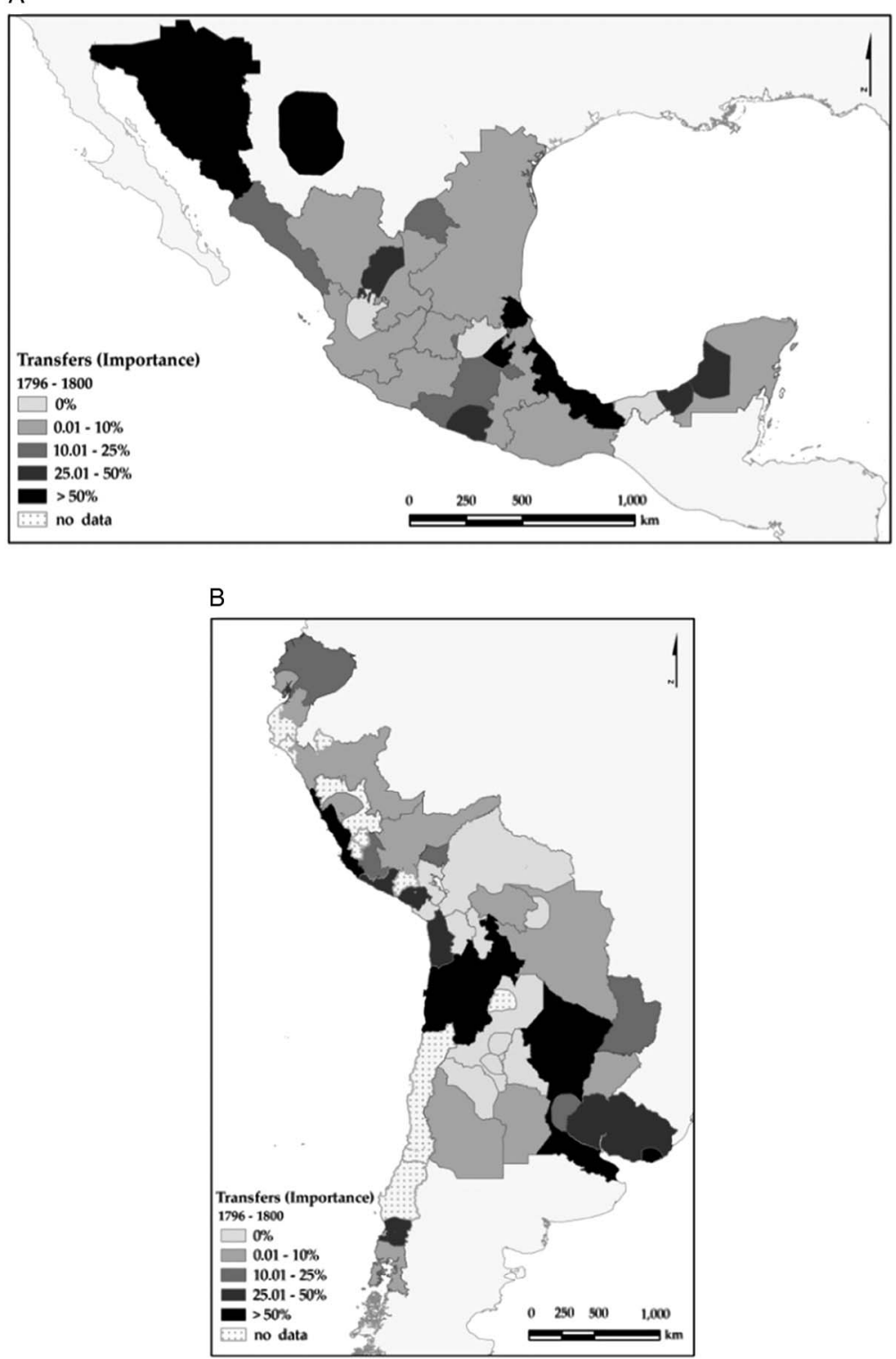
TABLE 1

TOTAL REVENUE, EXPENSES AND TRANSFERENCES TO SPAIN AND AMERICA, SELECTED YEARS IN PESOS

\begin{tabular}{|l|c|c|c|c|c|c|c|c|}
\hline & $\begin{array}{c}\text { Total } \\
\text { revenue }\end{array}$ & $\begin{array}{c}\text { Annual } \\
\text { growth }\end{array}$ & $\begin{array}{c}\text { Total } \\
\text { expenses }\end{array}$ & $\begin{array}{c}\text { Annual } \\
\text { growth }\end{array}$ & To America & $\begin{array}{c}\text { Annual } \\
\text { growth }\end{array}$ & To Spain & $\begin{array}{c}\text { Annual } \\
\text { growth }\end{array}$ \\
\hline $1691-1695$ & $43,195,438$ & & $43,219,682$ & & $13,059,053$ & & $5,047,838$ & \\
\hline $1729-1733$ & $50,394,431$ & 0.4 & $52,145,319$ & 0.5 & $13,854,670$ & 0.2 & $5,548,888$ & 2.66 \\
\hline $1785-1789$ & $255,194,445$ & 2.9 & $220,817,011$ & 2.56 & $92,207,404$ & 3.4 & $11,791,137$ & 1.4 \\
\hline $1796-1800$ & $413,710,965$ & 4.5 & $384,517,409$ & 5.17 & $124,655,854$ & 2.8 & $21,591,802$ & 5.7 \\
\hline
\end{tabular}

Source: Grafe and Irigoin (2012). 
It seems paradoxical that intra-colonial transfers skyrocketed at the time when Madrid tightened metropolitan control; they represented a third of the total money collected and the proportion varied further within districts. Expenses grew even faster than revenues and despite the growth in royal remittances to Spain (not accounting for private monies ${ }^{7}$ ) the initial low levels make relative their importance in the total tax take. Like Cuba and Buenos Aires, some regions benefited greatly at the expense of others according to their participation in the private-public partnership that managed the transfers (and the treasuries) in America. The diversion of income from more populated (more consumers) regions to coastal (trading overseas) and administrative centres is visible in Table 3. Thus, disproportion between costs and benefits among colonies was inbuilt in the system and it would inevitably create regional inequalities once the system failed.

\section{INDEPENDENCE}

This happened in 1808 when Napoleon forced the abdication of King Charles IV and imprisoned his heir, the future Ferdinand VII. The population rejected the French surrogate king with crucial institutional consequences. The manoeuvre was preventing the legitimate ruler from ruling; without a proper succession mechanism as the sovereign was still alive, the rejection of an «illegitimate» rule opened an unprecedented constitutional crisis. Spain waged its own «War of Independence» in Europe. Representatives of all parts of the Spanish monarchy - including the colonies on equal footing with metropolitan Spaniards - assembled in Cadiz to establish a provisional government of sorts. This congress hurried through a constitution in 1812 altering the nature of the political regime towards a somewhat representative constitutional monarchy, though the complete transition took the rest of the century.

In America elections of deputies to the Cadiz Congress gave way to provisional governments in every sizable urban centre - most of them also treasury sites. With the need to establish a new sovereignty and some form of governance a number of political and constitutional experiments developed (Dye 2006). Between 1808 and 1830, fifteen future nations in South America sanctioned forty-six constitutions ${ }^{8}$. By 1825 , most of them had turned into a republican form of government, some structured in a federal or confederal form, others centralised, but for the most part these were mere words. Thus, a centrifugal process of territorial fragmentation triggered the political, fiscal and finally monetary disintegration of the empire and the system of intra-colonial transfers disappeared altogether. Thereafter,

7 Prados de la Escosura (1993, pp. 263-264) estimates the value of private silver in 1782-1807 around 16,000,000 pesos, an amount slightly lower than that of Spain's commercial deficit.

8 Numbers do not include charters at subnational level. Source: political database EAW School of Foreign Service Georgetown University http://sfs.georgetown.edu/ 
competition for revenues and resources further prejudiced the loss of income from missing transfers; regional disparities evolved into civil war.

What were the economic consequences of such an exogenous shock? Maddison's data show a sharp fall in per capita GDP after 1820, which helps to explain why Latin America fell behind during post-independence (Coatsworth 1998). Prados de la Escosura (2009) challenges this notion as he argues that the region grew moderately on average and in this period outperformed other parts of the world with which a comparison is more realistic than using the United States as a yardstick ${ }^{9}$. Two other arguments posed by Prados de la Escosura refer neatly to the legacy of Spanish colonialism. Namely, (1) that net benefits from the release of the fiscal and trade burden imposed by the metropolis were offset by the costs of establishing an independent political regime and, a less surprising one, (2) that location and endowments prejudiced the efficient distribution of the expected gains from a "less costly» integration into the world economy. These two issues are central to the argument on the fiscal developments resulting from the end of the colonial rule made in this paper.

Prados de la Escosura is not conclusive regarding the extent to which the disappearance of the tax burden might have brought relief to the colonies. Representing 35 per cent of total foreign trade between 1783 and 1810, Spain's loss of her colonies did not mean a major setback for her economic activity ${ }^{10}$. Marichal (2008, p. 54) estimates that the burden the empire laid with the Mexican taxpayer was 50 per cent higher than what was paid by metropolitan subjects; 3.6 pesos per capita in America against 2.5 in Spain. In an earlier article, Coatsworth (1978, table 2) calculated that the losses for Mexico from restrictive Spanish policies amounted from 5 to 7.5 per cent of GDP representing a trade burden of 3 per cent of GDP or 1.20 pesos per capita and a fiscal burden of 1.68 pesos per capita - equivalent to 4.2 per cent of GDP. This made the burden of Spanish colonialism «35 times greater than that of Britain»; yet the thirteen British colonies embarked on a fiscal rebellion against the metropolis in the 1770s as a result and yet no equivalent reaction was ever recorded in Spanish America.

All these authors expect that the release of such a burden should bring economic advantages to the independent governments. As Marichal (2008, p. 257) states

If the external transfers (tax transfers to the metropolis and to other Spanish American colonies) had not been realized, New Spain's annual tax burden would have been reduced (...) This income, in the

9 Without a systematic assessment the argument is repeated for some particular cases (Llopis and Marichal 2009).

10 Prados de la Escosura (1993, p. 284) concludes that «fiscal insufficiency from a weak fiscal base together with the weakness of Spanish manufacturing at the time may explain the critical economic situation following the loss of the empire in mainland America» author's translation. 
hands of the taxpayers, would certainly have generated greater consumption, but might also have increased savings ... With regard to savings, it may be presumed that wealthier groups would have increased their silver holdings or invested them in trade or enterprise.

The quality of comparable GPD data for all districts is very uneven so a different estimate has been constructed where robust population data are available. Table 2 shows estimates for per capita net revenues and net expenditures, that is, exclusive of all remittances to neighbouring treasuries and to Spain for the regions that would become independent republics.

By the end of the century, the fiscal burden had increased in Mexico, but per capita net expenditure - exclusive of transfers - grew even more. Largely privately managed, substantial remittances to Cuba, other Caribbean posts and territories in today's United States, ought to render economic benefits to some (if not to the average) Mexicans. There is plenty of qualitative evidence showing the participation of Mexican merchants in the management, transport and apportioning of these remittances: the financing of the Tobacco royal monopoly is a clear example (Irigoin and Grafe 2008; Marichal and Grafenstein 2012). So, if gains were not evenly distributed, is it fair to assume that the per capita burden was even? Before addressing this point a clarification about the role of transfers is due.

The per capita tax take cannot capture the fiscal burden fully if equivalent amounts were ploughed back into the district by means of spending. Colonial treasuries rarely performed in deficit as expenditures, total and net per capita, always matched revenues. This is a result of the very nature of the data, that is, reports of the state of treasury to the king. It is thus anachronistic to interpret the flow of transfers in terms of deficits or surpluses. Indeed treasuries spent what they obtained as revenues - cash flow needs were sourced from local lending while waiting for the remittances to clear the debts. This does not mean that treasuries did not borrow, as suggested by the absence of interest-bearing loans in the records; they did it by other means, and heavily as will be seen below.

More importantly these transfers meant a sizable disparity in the burden of the contribution of American subjects to the royal purse. As seen in Table 3, the River Plate, Buenos Aires and Montevideo, could (and did) spend well above their genuine income - and by a substantial disproportion of their income. Conversely, in most of Bolivian treasuries revenues were not spent locally, that is, only half or less remained invested in the same district. Treasuries in Peru as a whole in the 1780s recorded 50 per cent of extra spending over their genuine means, which was shouldered by taxpayers elsewhere. Overall, locally raised revenues made up only half of what treasuries spent in the region before transfers, so arguably the regional distribution of the fiscal burden was indeed very uneven. 
TABLE 2

GROSS AND NET ${ }^{\text {a }}$ PER CAPITA REVENUES AND EXPENDITURE BY $19^{\text {th }}$ CENTURY POLITICAL AGGREGATES

\begin{tabular}{|c|c|c|c|c|c|c|c|c|}
\hline & $\begin{array}{c}\text { Revenue } \\
(1785- \\
1789)\end{array}$ & $\begin{array}{c}\text { Revenue } \\
(1796- \\
1800)\end{array}$ & $\begin{array}{c}\text { Net } \\
\text { revenues } \\
(1785- \\
1789)^{\mathrm{a}}\end{array}$ & $\begin{array}{c}\text { Net } \\
\text { revenues } \\
(1796- \\
1800)^{a}\end{array}$ & $\begin{array}{l}\text { Expenditures } \\
(1785-1789)\end{array}$ & $\begin{array}{l}\text { Expenditures } \\
(1796-1800)\end{array}$ & $\begin{array}{c}\text { Net } \\
\text { expenditures } \\
(1785-1789)^{a}\end{array}$ & $\begin{array}{c}\text { Net } \\
\text { expenditures } \\
(1796-1800)^{a}\end{array}$ \\
\hline Mexico & 7.90 & 11.60 & 6.13 & 9.15 & 5.62 & 11.14 & 2.57 & 6.94 \\
\hline Chile & 1.71 & 5.25 & 1.21 & 5.11 & 1.40 & 2.80 & 1.28 & 2.78 \\
\hline $\begin{array}{l}\text { River } \\
\text { Plate }\end{array}$ & 6.90 & 8.42 & 3.16 & 4.29 & 5.38 & 7.67 & 4.87 & 7.16 \\
\hline Bolivia & 5.47 & 6.25 & 4.31 & 4.33 & 3.85 & 4.14 & 1.85 & 1.73 \\
\hline Peru & 5.39 & 3.51 & 4.49 & 2.28 & 3.80 & 3.09 & 2.98 & 2.00 \\
\hline Spain & & & & $3.17^{\mathrm{b}}$ & & & 2.77 & 5.59 \\
\hline
\end{tabular}

Notes:

${ }^{\text {a Net }}$ of transfers to Spain and other colonies.

${ }^{\mathrm{b}}$ Data for 1800 .

Source: Grafe and Irigoin (2012, table 1). 
Without uniformity in tax rates and exemptions, and without a single centralised fiscal authority the tax burden - measured by the per capita amounts transferred and received in each district - varied greatly within the same larger region. There was neither a single fiscal jurisdiction nor was there a single constituency in Spain or Spanish America ${ }^{11}$. In fact regional inequalities were embedded in the system. Tribute from indigenous population in Bolivia ranged between 6 and 13.6 pesos per capita (Klein 1993, table 3.15), so the average of 4.30 pesos for Bolivia as a whole masks a substantial dispersion in the burden of colonial taxation. Table 3 also shows the redistributive effects of the intra-colonial transfers throughout. It distinguishes those who gained: the main cities and the ports, from those who paid; in Mexico for instance, the big mining towns Durango, Guanajuato, Guadalajara, San Luis Potosi and Zacatecas, or the populous indigenous districts of South Peru. The observed negative sign for Mexico City is compensated by surpluses received in Veracruz - or Acapulco for which no population data are available. From these ports revenues were sent to Cuba, Spain and Manila and worked as capital for private trade.

This does not mean, however, that mining revenues were directly extracted. The collection of indirect taxes on trade and consumption fostered by silver dissemination within explains the multiplication of treasuries in the interior connecting mining towns and populated consumer centres with coastal trading ports. This structure persisted after independence and gave way to a number of internal customs within each new republic - distorting whatever benefits were to be obtained from freer trade. Hence, post-independence «free» trade legislation initially lowered the tariff at the ports, but internal customs still taxed goods moving inland. The alcabala, as an overland trade tax levied on domestic or foreign goods in transit, persisted well into the $19^{\text {th }}$ century and in Spain it was only abolished in 1845. Mexcans living in the capital had to pay an additional 15 per cent «introduction» surtax on consumer goods entering the city after 1821 (Sánchez Santiró 2009) so benefits from the «release of the trade burden» were lost in the poor integration of domestic markets. Thus, colonial taxation became the institutional legacy that dissipated any gains expected from greater openness to the international economy.

\section{THE LEGACY}

Economic historians explaining the 1820-1870 slump suggest politicalinstitutional causes: instability, warfare, fiscal and financial disorder. For Prados de la Escosura (2009), the «costs of self-government» and the «costs

11 Taxes were particular to individual territories. The treasury relied on tax farming and encabezamientos or contributions made by the ayuntamientos - town councils - in proportion to the population. Attempts to centralise the collection of taxes started in 1742 in some large Andalusian and Castilian towns without success. (Fontana 1987, pp. 22-26). 
TABLE 3

REGIONAL VARIATION OF TAX BURDEN, PER CAPITA (PC) REVENUES AND EXPENDITURES, AND TRANSFERS SELECTED TREASURIES C. 1800

\begin{tabular}{|c|c|c|c|c|}
\hline & Net revenues pc (1800) & Net expenditures pc (1800) & $\begin{array}{c}\text { Transfer pc 1796-1800 } \\
\text { annual average }\end{array}$ & Population \\
\hline Arequipa (Peru) & 5.39 & 3.87 & -3.34 & 37,721 \\
\hline Cuzco (Peru) & 12.15 & 7.56 & -5.17 & 32,082 \\
\hline Huamanga (Peru) & 6.80 & 4.49 & -5.03 & 25,970 \\
\hline Lima (Peru) & 5.24 & 8.87 & 6.67 & 201,259 \\
\hline Trujillo (Peru) & 18.13 & 12.15 & -10.22 & 17,700 \\
\hline Guayaquil (Ecuador) & 4.06 & 3.53 & n.a. & 39,045 \\
\hline La Paz (Bolivia) & 12.32 & 3.47 & -5.72 & 40,000 \\
\hline Potosi (Bolivia) & 18.29 & 17.03 & 4.75 & 35,000 \\
\hline Concepcion (Chile) & 5.23 & 2.76 & n.a. & 105,114 \\
\hline Chiloe (Chile) & 4.38 & 4.50 & n.a. & 26,703 \\
\hline Mendoza (Chile) & 4.61 & 1.46 & -0.16 & 8,765 \\
\hline Santiago (Chile) & 9.26 & 4.28 & n.a. & 203,732 \\
\hline Buenos Aires (River Plate) & 16.40 & 28.44 & 19.85 & 72,165 \\
\hline Montevideo (River Plate) & 40.31 & 49 & 7.32 & 14,093 \\
\hline Paraguay (River Plate) & 1.03 & 1.07 & 0.27 & 100,000 \\
\hline Salta (River Plate) & 4.58 & 3.98 & n.a. & 13,528 \\
\hline Santa Fe (River Plate) & 0.07 & 1.63 & -0.11 & 12,600 \\
\hline
\end{tabular}


TABLE 3 (Cont.)

\begin{tabular}{|c|c|c|c|c|}
\hline & Net revenues pc (1800) & Net expenditures pc (1800) & $\begin{array}{c}\text { Transfer pc 1796-1800 } \\
\text { annual average }\end{array}$ & Population \\
\hline Durango (Mexico) & 2.95 & 0.24 & -2.54 & 157,970 \\
\hline Guadalajara (Mexico) & 1.57 & 0.20 & -1.21 & 623,572 \\
\hline Guanajuato (Mexico) & 2.36 & 0.15 & -1.74 & 511,616 \\
\hline Merida (Mexico) & 1.06 & 0.62 & n.a. & 460,620 \\
\hline Mexico (Mexico) & 24.41 & 24.85 & -2.81 & $1,495,140$ \\
\hline Oaxaca (Mexico) & 0.92 & 0.09 & -0.51 & 528,860 \\
\hline Puebla (Mexico) & 1.36 & 0.46 & -0.09 & 821,277 \\
\hline SL Potosi (Mexico) & 2.83 & 0.16 & -2.68 & 311,503 \\
\hline Veracruz (Mexico) & 14.35 & 20.54 & 2.29 & 154,286 \\
\hline Zacatecas (Mexico) & 9.04 & 4.58 & -4.91 & 151,749 \\
\hline
\end{tabular}

Note: Shade corresponds to the respective large colonial administrative unit, that is, Viceroyalties; in brackets the corresponding $19^{\text {th }}$ republic. Source: Calculated from Grafe and Irigoin (2012). 
of administering political units» of a suboptimal size increased transaction costs that offset any benefits from the release of colonial - trade and fiscal burdens. Yet, earlier scholarship had found positive externalities from «more liberal» policies followed by Buenos Aires or Cuba, for example, which distinguished them as successful export economies from the more backward «closed» economies on the mainland. Some countries were more effective than others at creating «modern» institutions that better protected private property rights (Bordo and Cortés Conde 2001) - away from predatory caudillos - (Amaral 1993); or were more successful at creating more market-friendly institutions (Coatsworth 1993). Export growth and access to international capital markets mirror institutional success.

Indeed nearly all the states that emerged after 1808 in Spanish America and in the metropolis - dealt with the constitutional crisis with similar institutional designs. In America this was the cue for autonomy from neighbouring colonial authorities rather than for independence from Spain since de facto, the metropolis had very little control over their resources ${ }^{12}$. However, not all the colonies had enjoyed the benefits of being part of the same political compact in the same way as seen in Table 3. It is thus not surprising that the Plan de Gobierno de la Junta Tuitiva of La Paz (Bolivia) early in 1809 manifested the decision to cease sending money to Buenos Aires; while renewing allegiance to the imprisoned king (Roca 2007, p. 20). Each proclamation in the colonies following these events echoes this issue somewhat - even among those which initially remained loyal to the king. Autonomy from colonial authorities rather than independence from Spain was the issue. Regions with fewer treasury districts and more homogenous size, such as Chile or Ecuador, were relatively spared from these tensions (Alexander Rodriguez 1992).

Both metropolis and colonies sought an institutional solution in the Cortes of Cadiz. With colonial representation, the Cortes sanctioned a constitution to be the foundation for a provisional government for «las Españas». The charter conceived representation of «both hemispheres» in the Cortes and in the seven-member government to provisionally replace the king (art 7, 10). Population - as one single constituency - was to be represented «in proportion» erasing the historical territorial jurisdictions, for example, one deputy for every 70,000 people according to the 1797 census for Spain. There was, however, no counting for population in America (art 31). This threshold left the majority of medium-sized and small towns - that is, the great majority of treasury districts - without representation (art 32-33) and conferred political control on large colonial cities. Moreover, citizenship as a political right was granted to all males who were «not broke or servant,

12 It may be slightly inaccurate to assign to 1808 the drive for independence in the colonies. Conservative policies of the restoration governments in 1814 precipitated such reaction that ended up with the separation, formally, by 1820 and the «liberal» revolution in Spain. 
nor unemployed or a felon»; as a means to incorporate individual subjects to a single constituency — abrogating privileges that is, fueros — was equally ambiguous. There were no property restrictions to suffrage and, remarkably, literacy was to become a requirement only after 1830 (art 25). The mita and personal tribute were abolished. To this, first constitutional texts in America added the end of the slave trade and the emancipation of slaves. Famously, the 1821 Plan de Iguala in Mexico recognised all inhabitants, Europeans, Africans and indigenous alike as citizens "without distinction» (art 12) and like most early charters incorporated the vast majority of male citizens into an inclusive but vaguely defined nation-state. Similar liberality regarding political and civil rights appears in early constitutional charters such as Venezuela (1811), Antioquia (1812), or Peru (1821) (Pérez Herrero 2010).

On these bases for representation the Cortes filled in the legitimacy vacuum. The 1812 text was mostly concerned with the constitutional role of the king and of the Cortes. The new form of government was defined as «moderate monarchy» (art 14) and representation of the constituents was consistent with Spanish tradition (Guerra 1994). Direct election was the means to appoint new legitimate authorities. Political historians have convincingly shown that elections were a widespread practice of the late $18^{\text {th }}$ century political culture (Benson 1946; Posada-Carbó 1996). Thus, with the 1808 crisis, now contested elections repeated in vice regal capitals as well as in pueblos de indios or small towns across of Spanish America (Warren 1996; Caplan 2003; Echeverri 2015; Ternavasio 2015; Sartorious 2015 for Cuba's exceptional case) and the 1812 charter organised the template for popular sovereignty and the recognition of equal political rights for all citizens (Eastman and Sobrevilla Perea 2015). The Buenos Aires constitution of 1821 granted universal male suffrage - which was replicated later in other provinces (Annino 1995). In some places, participation was initially high - for example, Santiago, Bogota, Buenos Aires - but turnout steadily reduced over time ${ }^{13}$. Between 1812 and 1854, Mexico only sanctioned thirty-five electoral laws and statutes that reformed the mechanism of elections, making procedures more arbitrary and placing ever more stringent restrictions for example, wealth, property, age, literacy - to franchise (Garcia Orozco 1978). This makes it clear that the exclusionary character of Latin American politics is not a direct legacy of colonialism; but rather an outcome of $19^{\text {th }}$ century politics. Nonetheless, elections were held at irregular intervals; they systematically occurred just after a revolution to invest legality to the new order, thus developing more a perfunctory role of ex post legitimisation (Halperin Donghi 1979; Fowler 2010). Thus, the nature of the Spanish monarchy, formerly based on privileges and hierarchies of corporate

13 Turnout in 1820s Bogota was around 15 per cent (Deas, 1996). The 1824 Mexican Constitution established biannual elections for Congress. However, between 1821 and 1855 there were twenty-two elections (Aguilar Rivera 2010, p. 13). 
subjects and historical territories arbitrated by the king, was altered for an ill-defined popular sovereignty in a territorial compact whose constituents were now individuals all equal before the treasury. Yet, the fiscal basis to sustain such a state remained de facto unchanged. Ambiguities regarding territorial and individual representation in fiscal matters are one major institutional legacy of the Spanish Ancien Regime and colonialism.

The chapter on taxation is very short; only seventeen of a total of 371 articles, and is particularly ambiguous about sources of revenues and prerogatives of the state to collect taxes. Cortes to be elected was to establish or «confirm taxes, direct or indirect, provincial or municipal» in the future. In practice, the charter allowed for the continuation of existing taxes «until new levies were established». Consistent with the liberal rhetoric taxes were to be borne by all Spaniards in "proportion of their facultades» and the king's prerogative to grant privileges and exemptions to individuals and corporate bodies was abrogated. This aimed to establish a uniform - and wider fiscal base but said nothing about particular fiscal regimes in the peninsula such as the Basque country or Navarra, nor made any special reference to the transfers between (or out of) the colonies. Article 11 listed the territories comprising «Spain in America, Asia and Europe» and postponed «the division of this territory by a constitutional law for a convenient time political circumstances permitting». Notably, article 340 established that «taxes were to be proportional to expenditures» disregarding the identity principle that treasuries need to collect in order to spend ${ }^{14}$. Territories were to be subject to an unspecified direct contribution "contribución directa» to be apportioned among the provinces «according to their wealth» without any indication of its source or a mechanism to assess it.

Aiming for greater centralisation, one general treasury was to be created at the head of a set of similar single treasuries in each of the unspecified provinces; however, collection remained in the hands of the towns, that is, ayuntamientos and cabildos (art 321-323). Revenues should thereafter be sent to the main treasury districts where authorities decided about spending. This additional lack of identity between the agents who spent and those who collected revenues was to be crucial thereafter. Article 354 abolished all customs "other than maritime and at the borders», but the borders were not defined (art 11); so in America internal customs appeared between former treasury districts - now autonomous - and the fiscal autonomy of historical territories in the metropolis persisted. The charter admitted that the public debt was «a matter of the first order importance» (particularly, after the failed consolidation of the vales reales), however, it did not earmark revenues for a sinking fund - or make any effective decision on the debt that mattered. Notably, as per article 131, the Cortes was to determine the value,

${ }^{14}$ Official budgets in 1840s Spain still conceived nearly a 50 per cent deficit without any provision to meet the gap (Tedde de Lorca 1994, pp. 32-33). 
weight and fineness of the silver and denomination of the coins, without a mint or a bank with which to implement it. A final very short chapter on education with six articles (366-371) promised free access to primary schools and even allowed for the creation of universities but with no indication of the means with which to do so.

Two major constitutional issues were not resolved: the representation and the aggregation of territories and subjects constituents of this state and the means to fund it accordingly. This double ambiguity meant an unsurmountable limitation to the fiscal sovereignty of the state, which only exacerbated the ongoing institutional crisis. The existing economic and fiscal disparities among districts made it even less feasible to incorporate them into new sovereign polities. The deep local roots of the structure of taxation from pervasive tax farming, sale of office and privileges were a formidable obstacle to any subsequent negotiation regarding the territorial integration of treasuries. With local autonomy - and without a clear sovereign - the fiscal compact disintegrated. Lacking legitimacy, public property rights to taxation disappeared and without transfers from other districts' governments income everywhere reduced sharply. Legitimacy to rule and to tax was put into question and any successive political aggregation at a broader regional scale such as the Gran Colombia, the Central America Confederation and the Provincias Unidas del Rio de la Plata, quickly failed.

These were the costs of independence. Focussing on the disintegration of the empire, however, has overshadowed the fact that the political and fiscal history of the metropolis is very comparable; there too the process of political «aggregation» and fiscal constitution of a popular sovereignty proved as haphazard. The failure of every political compromise led to war over resources and revenues while military spending fuelled public deficits and mounting debts. But war and disorder have not been an impediment for the making of strong states - and successful economic development - as the literature on the fiscal military states in modern Europe attests. Unable to pay for allegiance or recruits, revolutionary governments in America offered very generous entitlements to large sectors of the population. Tax exemptions, tariff reductions, and entitlements, that is, a wide definition of citizenry to all Americans, elimination of tribute, emancipation of slaves, direct elections to appoint army officials, etc. did not always provide an immediate yield to the treasury but helped to mobilise support without money. These measures also created a significant if confusing set of rights - civil, social and political — available to all individuals in their own transition from subjects of the King to citizens of the republican states.

\subsection{Representation Without Taxation}

Seeking to broaden the fiscal base of the republican state, governments in the 1820s tried to move away from indirect trade and consumption taxes to 
more direct contributions - echoing the rhetoric about representation of the 1812 charter. Probably, the most dramatic reform programme was that of General Sucre in Bolivia, which abolished the mita, the tobacco monopoly and the alcabala together with the indigenous tribute. Instead, it devised a direct, universal levy on every Bolivian - the non-descript contribución directa - which was rejected by all parties affected and abolished within 3 years ${ }^{15}$. Under Spanish rule, indigenous people paid tribute but had been exempted from the alcabala; the rest, white, free blacks and mestizos alike paid this sales tax but did not pay any head taxes. In Mexico, the 1821 Federal Constitution abolished the tribute and granted the levy of direct taxes to state (provincial) governments; however, regional elites rejected the new taxation and by the 1830s most states had further increased indirect contributions like alcabalas and monopolies. A few populous states like Oaxaca and Yucatan continued the indigenous capitation and the tithe from which they obtained the bulk of their income well into the 1840s (Serrano Ortega 2007). Tribute was also abolished in Ecuador in 1823 - to be re-established within 3 or 4 years - and in Peru by the 1821 reforms together with the alcabala. Yet, tribute did not cease completely until 1895 (Contreras 2006). This contrast between Mexico and Peru is explained by the greater commercial orientation of the Mexican indigenous economy. The relatively greater dispersion of silver mining in Mexico may also explain the choice for the persistence of the alcabala until the 1857 constitution (on paper) and beyond, until 1896, in practice (Jauregui 2010). In any case this feature, which troubled the integration of the domestic economy, mirrors the different degree of centralisation that Peru enjoyed over Mexico - and the respective path in their constitutional designs ${ }^{16}$.

The fiscal reforms of the 1820s in Latin America - including those of Rivadavia in Buenos Aires, San Martin in Peru (Anna 1974), Santander in Colombia (Bushnell 1953/1970) and Sucre in Bolivia (Lofstrom 1970) failed on three main counts such as to establish direct taxation, to increase revenue collection and to build fiscal capacity. The same happened with the 1813 reform in Spain. Paradoxically, the failure reinforced central governments' dependence on customs and monopolies even further (Centeno 2002). Tariffs in the hands of central governments continuously increased throughout. Taxes mainly levied on imports made up at least half of revenues as in Mexico and 80 per cent of revenues in most other countries. With the continuation of the colonial alcabala the fiscal burden fell squarely on consumers. A few countries, such as Peru, obtained similar income from taxes on guano exports after 1850 or Chile, later, with a similar near monopolistic

15 It consisted of a vaguely defined personal or head tax, partly a property tax and partly an income tax. Indigenous villages rejected them to keep ownership of communal lands (Platt 1982; Sánchez-Albornoz 1978).

16 Republican governments in both cases replaced the mining tithe - which was collected by the church — with a 3 per cent tax (Contreras 1999). 
position in the production of nitrates. For most of the period in Chile and Mexico, the colonial tobacco monopoly still constituted 60 per cent or more of total revenues (Tenenbaum 1986). Together with the salt monopoly, it represented 60 per cent of revenues in Colombia until the 1850s. Elsewhere land sales, either public as in the River Plate or expropriated from the church as in Bolivia or from indigenous villages as in Colombia (Halperin Donghi 1979; Abendroth 1990; Kalmanovitz 2006) occasionally rendered additional revenues.

Yet, the per capita tax take of republican governments was lower than what the colonial treasury had extracted. Assembling information from a patchwork of sources for population and revenues, Table 4 shows the estimated fiscal burden for comparable districts in years for which data are available. Caution is in order as the robustness of the indicators is debatable so real values are no more than a makeshift ${ }^{17}$. These are all nominal values but price data are even more paltry; possibly the best available estimate of $19^{\text {th }}$ century living standards is that of Peru (Gootenberg 1990), which basically considers prices in Lima only. Yet, comparing with estimates displayed in Table 2, the government's tax take had reduced dramatically in the Mexican Federation, Chile, Peru and Bolivia, and this situation is repeated when comparing the colonial fiscal burden at district level shown in Table 3. Veracruz's dramatic fall mirrors the end of the intra-colonial transfers; other Mexican states' governments had lost half or more of their nominal value in 1800 in spite of the fact that population remained stable or migrated to larger cities.

Back in 1989, Nils Jacobsen estimated that per capita collection of revenues in Peru had fallen from « 28.9 reals in the mid-1790s to 23.3 reals in 1850». This reduction of almost 20 per cent in the nominal value of the collection represented about 43 per cent in real terms as he assumed «a 30\% inflation rate for the period 1800s and 1850s» (Jacobsen 1989, p. 315). More recent data show successive cycles of deflation and inflation as the result of lower levels of silver in circulation and inflationary financing of wars before the guano boom (Gootenberg 1990, pp. 28-30). This explains the relatively higher tax burden of the 1840s. Otherwise, as in Mexico, the tax take of the republican government was a fraction of the colonial burden in spite of moderate price inflation (Challu and Gómez Galvarriato 2015).

In Spain, the 1843-1845 Mon Santillán reforms - together with a new constitution - abolished internal customs with the discontinuation of alcabalas. Exemptions and tax farming still in hands of ecclesiastics, corporation and wealthy individuals notwithstanding, they granted a slightly greater fiscal return to the central government (Serrano 2010). Yet, in the

17 Unlike colonial data used in Table 3, Table 4 data state gross revenue indiscriminately and include carryovers and financial income of all sorts. Systematic counting of the population -itself a measure of state capacity — started only in the second half of the century in most republics. 
TABLE 4

ESTIMATED PER CAPITA FISCAL BURDEN, SPANISH AMERICA 1820-1850

\begin{tabular}{|c|c|c|c|c|c|}
\hline & & Gross revenue & Population & Per capita revenue & Real per capita revenue \\
\hline \multirow[t]{3}{*}{ Chile } & 1800 & & & $5.11 *$ & \\
\hline & 1835 & $2,003,421$ & $1,010,332$ & 1.98 & \\
\hline & 1843 & $3,063,568$ & $1,038,801$ & 2.94 & \\
\hline \multirow[t]{9}{*}{ Mexico 1800} & & & & $9.15^{*}$ & $* *$ \\
\hline & 1825 & $8,567,954$ & $6,500,000$ & 1.31 & 11.64 \\
\hline & 1827 & $15,173,469$ & $8,000,000$ & 1.89 & 1.51 \\
\hline & 1830 & $17,776,870$ & $7,996,000$ & 2.22 & 2.36 \\
\hline & 1831 & $16,040,591$ & $6,382,284$ & 2.51 & 2.22 \\
\hline & 1834 & $17,737,883$ & $7,734,292$ & 2.29 & 3.48 \\
\hline & 1842 & $18,865,148$ & $7,015,509$ & 2.68 & 2.7 \\
\hline & 1844 & $22,194,712$ & $7,000,000$ & 3.17 & 3.63 \\
\hline & $1841-44$ & $19,262,682$ & $7,015,509$ & 2.74 & 4.46 \\
\hline \multirow[t]{3}{*}{ Buenos Aires province } & 1800 & $2,782,669^{\mathrm{a}}$ & 72,615 & $38.55^{*}$ & 38.55 \\
\hline & 1819 & $2,408,242^{b}$ & 125,000 & 19.26 & 19.26 \\
\hline & 1829 & $7,915,579$ & 153,000 & 51.73 & 13.90 \\
\hline
\end{tabular}


TABLE 4 (Cont.)

\begin{tabular}{|c|c|c|c|c|c|}
\hline & & Gross revenue & Population & Per capita revenue & Real per capita revenue \\
\hline \multirow[t]{3}{*}{ Bolivia } & 1800 & & & $4.33 *$ & \\
\hline & 1827 & $1,867,041$ & $1,100,000$ & 1.69 & \\
\hline & 1846 & $2,363,034$ & $1,378,896$ & 1.71 & \\
\hline \multirow[t]{6}{*}{ Peru } & 1800 & & & $2.28^{*}$ & 1.73 \\
\hline & 1826 & $3,346,032$ & $1,500,000$ & 2.23 & $1.98 * * *$ \\
\hline & 1830 & $3,003,489$ & $1,249,723$ & 2.40 & $2.40 * * *$ \\
\hline & 1831 & $3,526,148$ & $1,373,736$ & 2.56 & $2.65^{* * *}$ \\
\hline & 1846 & $5,515,591$ & $1,373,736$ & 4.01 & $4.93 * * *$ \\
\hline & 1850 & $7,029,112$ & $2,001,123$ & 3.51 & $4.28 * * *$ \\
\hline \multicolumn{6}{|c|}{ Mexican states } \\
\hline \multirow[t]{3}{*}{ Durango } & 1800 & & & $2.95^{*}$ & \\
\hline & $1825-26$ & 312,479 & 120,157 & 2.60 & \\
\hline & 1833 & 391,091 & 139,081 & 2.81 & \\
\hline \multirow[t]{2}{*}{ Mexico } & $1826-27$ & 892,130 & 829,458 & 1.07 & \\
\hline & 1833-34 & 728,270 & $1,039,758$ & 0.70 & \\
\hline \multirow[t]{3}{*}{ Guanajuato } & 1800 & & & $2.36^{*}$ & \\
\hline & 1829 & 733,444 & 442,916 & 1.65 & \\
\hline & 1831 & 654,853 & 494,823 & 1.32 & \\
\hline
\end{tabular}




\begin{tabular}{|c|c|c|c|c|}
\hline Jalisco/ Guadalajara & 1800 & & & $1.57^{*}$ \\
\hline & 1830 & 614,858 & 656,881 & 0.93 \\
\hline & 1831 & 505,443 & 660,595 & 0.76 \\
\hline & 1834 & 532,600 & 680,000 & 0.78 \\
\hline Puebla & 1800 & & & $1.36^{*}$ \\
\hline & 1825 & 405,618 & 584,358 & 0.69 \\
\hline San Luis Potosi & 1800 & & & $2.83 *$ \\
\hline & 1828 & 470,050 & 297,593 & 1.57 \\
\hline & 1830 & 448,500 & 310,196 & 1.44 \\
\hline Veracruz & 1830 & 241,659 & 242,658 & 0.99 \\
\hline Zacatecas & 1800 & & & $9.04 *$ \\
\hline & 1825 & 620,018 & 247,295 & 2.50 \\
\hline & 1826 & 689,032 & 272,901 & 2.52 \\
\hline & 1830 & 844,049 & 274,537 & 3.07 \\
\hline & 1832 & $1,476,757$ & 314,121 & 4.70 \\
\hline
\end{tabular}

Notes: *Data from annual average «net per capita revenues» 1796-1800 Grafe and Irigoin (2012, table 2); **Mexico adjusted by annual CPI value in silver grains index from Challú and Gómez Galvarriato (2015); ***Peru: adjusted by annual inflation index from Gootenberg (1990, table 3).

${ }^{\mathrm{a}}$ Annual average net per capita revenue for Buenos Aires only.

${ }^{\mathrm{b}}$ Data for 1822 (Burgin 1947, p. 53, table 7). 
1850s the bulk of revenues still originated from customs, monopolies and other consumption taxes (Yun Casalilla et al. 2012). A new direct tax known as the «contribución territorial» did not yield; this ill-defined levy on land property (not on income or capital) left the valuation and collection of taxes in the hands of ayuntamientos. Various disentailments of royal and church real estate $(1811,1836-37,1841,1855)$ to pay old debts or paid with depreciated scrip provided some occasional income but, as in Spanish America, large sales of lands distorted land markets and fostered the concentration of assets.

Everywhere "Liberals and Absolutist» (or conservative) governments alike faced the same fiscal problems and resolved them in very much the same fashion: repeated insolvency, further indebtedness and further indirect $\operatorname{taxes}^{18}$. This was not a matter of politics or ideologies. In Buenos Aires, for instance the same individual, Manuel Garcia, was responsible for finances for 15 years and served under diametrically different governments - in the eyes of political historians - those of Rivadavia and Rosas (Irigoin 2000). Frequent changes of governments in both former colonies and metropolis are a symptom of protracted instability but comparable changes at the head of the treasury intimate that this was far from a legacy of colonialism. Between 1827 and 1855, Mexico had fort-nine different governments and 119 ministers of finance, who lasted an average of 4 months in office if the government was constitutionally appointed, or barely 3 weeks in the de facto regimes. In the metropolis, between the French withdrawal in 1814 and the 1868 revolution, there were fifty-four cabinets and ninety-two different ministers of finance ${ }^{19}$.

Indeed both Spanish and Spanish American governments became insolvent in the wake of the crisis following the Napoleonic occupation of Spain and their - commercial and fiscal - deficits continued with force (Comin 1988). Both colonies and metropolis amassed huge domestic debts and borrowed heavily in European capital markets; cash-strapped Spanish American republics found ready money in London in the $1820 \mathrm{~s}$ and applied fresh funds to make their reforms viable. Within a few years they had all defaulted and remained sealed off from further foreign borrowing for the next 40 years (Marichal 1989). Only when governments restored some soundness to their treasuries were they to become credible borrowers in London again. Spanish governments did slightly better; they repeatedly defaulted or repudiated the domestic debt $(1836,1840)$ (Tedde de Lorca and Marichal 1994, p. 64). Spain was also able to borrow in London in the 1820s and in France in the early 1830s; adding this debt to the arrears from the Dutch loans of the 1800s (Canga Arguelles 1833) - but lost direct access to

${ }^{18}$ In Spain the government unilaterally restructured the debt as in 1818, repudiated it (partly) in 1828 , defaulted or nearly defaulted in 1836 and 1847 .

19 Numbers count the ministers, some individual names repeated in the post. For Mexico: (Stevens 1991); for Spain: (Urquijo Goitia 2015). 
foreign finance in the late 1830s (Platt 1983, p. 124). Thereafter, the government could only survive with short run lending from the house of Rothschild - but at a significant fiscal cost: the loss of revenues from one of the world's most important quicksilver deposits ${ }^{20}$.

\subsection{Taxation Without Consent}

In the 1820s most of the republics also consolidated their debt including arrears from old colonial claims. In Mexico by 1816 it represented 120 per cent of the total revenues of the Mexican treasury in the bountiful years of 1800s; the proportion was 300 per cent for Lima in 1821 and 150 per cent in Buenos Aires ${ }^{21}$. The three treasuries had been major recipients of transfers before 1810 so without these extra revenues the debt burden was several times larger in the 1820s (Grafe and Irigoin 2012, p. 629). As part of the reforms some republican governments launched their first public debt issues. Early on Buenos Aires chartered a private bank of issue and established a stock exchange as a marketplace for public funds and foreign exchange. The funded debt in 1821 amounted to twice as much as the yearly treasury revenue at the time. By 1840 it had multiplied tenfold as it helped to fund the customs shortfall from European blockades to the port. Unsurprisingly bonds as a financial resource vanished; a twentyfold increase in the volume of the fiduciary currency issued by the bank and a subsequent depreciation of the exchange rate with gold that fell from 17 to 370 pesos in the same period annihilated the domestic market for government debt (Irigoin 2000).

By 1821 Spain's domestic debt — which included the principal and arrears of the failed Vales Reales - represented about the same amount as annual revenues (Prados de la Escosura 1993; Tedde de Lorca 1999, p. 12, table 10). The metropolis had lost the fiscal returns from re-exports of other European goods to the colonies and revenues from trade services had collapsed. Spain was still able to borrow abroad for a while. After 1834 shortterm bills - mainly from France - multiplied the nominal volume of external debt. It was already twenty times larger than in 1821 and it grew another 50 per cent in the subsequent 15 years (Sardá 1948, pp. 60-90). Established in 1829 on the remains of the failed Banco de San Carlos, the

20 In 1835 the Almaden mines were leased to Rothschild. Mercury was a critical input for the refining of silver and the house controlled the refining of precious metals in Paris and London, which made it dominant in the exchange business in Europe (Lopez Morell 2013, p. 83, figure 12.10)

${ }^{21}$ The amount of the certified debt was 21.6 million pesos in Mexico, 21.7 million in Peru and 4 million in Buenos Aires (Grafe and Irigoin 2012). Using Coatsworth's (1998) GDP data these figures represent 10 per cent of Mexican GDP, 50 per cent of Peru's GDP and 16 per cent of Argentina's GDP. The figure for Spain was 13,120 million reals but 60 per cent of it was repudiated by the government in 1828 (Tedde de Lorca 1994, p. 12). 
Banco de San Fernando - with limited large operations confined to Madrid - issued notes to lend to the government without building equivalent metallic reserves. (Sardá 1948, p. 32; Tedde de Lorca 1999, p. 30). The bank assisted the government during the Carlista war and it helped further with an extraordinary issue of notes without reserves - as fiduciary money in 1844-1847 (Sardá 1948, p. 94; Tedde de Lorca 1999, table 1.4). It merged with the Banco de Isabel II in 1847, which multiplied its issues even more. Funding the government debt represented 60-70 per cent of the bank's assets and crippled the peculiar banking system of the country as Tedde de Lorca has painstakingly described. Unsurprisingly, lending to private business was minimal. Yet, the financial reform and creation of the Banco de España in the 1850s did not end the recourse to finance debt by monetary means; it would turn into open inflationary finance policy later in 1883 with the inconvertibility of the peseta (Martín Aceña 1981).

Thus, recurrent deficits were increasingly financed with debt (which was often restructured) or money creation when both foreign and domestic lenders had been exhausted. In some countries the last resort eventually was money creation by means of rigging the banks as was the case in 1840s Spain, debasing the currency as in 1830s Mexico or 1850s Bolivia, or just printing fiat money as in Buenos Aires in 1826 (Mitre 1986; Torres Medina 1998; Tedde de Lorca 1999; Irigoin 2000; Centeno 2002). This also triggered a remarkable change in monetary policy with lasting impact; the expansion of currency to meet fiscal disequilibrium opened an early door to governments to use money as a fiscal instrument. Depreciated exchange rates hence also provided additional protection and stimulated the production of some exports - especially when international prices were falling - despite scholars' insistence on the importance of tariffs throughout the $19^{\text {th }}$ century (Coatsworth and Williamson 2004). Effects of the monetisation of the deficit further disintegrated money markets and exacerbated regional and political tensions within a formerly integrated monetary union.

According to Spanish monetary historians a "contradictory» monetary policy, particularly after 1823, failed to attract specie to the mint (Sardá 1948), imposing substantial deflationary effects on the Spanish economy (Sardá 1947; Nogués-Marco 2005 for a qualification). Throughout, a systematic - but unexplained - overvaluation of silver drove specie out of circulation; for example, the gold/silver exchange rate was 1:15.2 in the United Kingdom, 15.5 in France and 16.5 and even 16.7 in Spain, so «Spanish coins were hence hoarded or exported en masse». Thus, insufficient circulating medium sustained demand for lesser quality French coins for decades. Liberal governments hoped to revert this early in the 1820s without success. The 1824 Restoration's monetary policy was notoriously prejudicial and the flight "of pesos duros or fuertes» continued despite large foreign loans. Deflation was significant until 1830 and continued through the 1840 s (Carreras 2005, table 16.9, pp. 1288-1290) despite the re-opening of the 
Barcelona mint and renewed coinage in Madrid (Sardá 1948, pp. 80-88). Other foreign coins, Mexican and Portuguese, even entered circulation increasing the disorder. Without means governments were unlikely to run a mint or any foreign exchange policy effectively, so low coinage it is no wonder.

Yet, it is unclear which Spanish silver coins were dominant in circulation; according to Sardá (1948, p. 67) these were pesos «fuertes or duros' with higher intrinsic silver value than French coins, and were most likely good Spanish American pesos. As in Peru, and elsewhere, from the mid-1820s to the mid-1830s good silver coins were siphoned off, given their appreciation in France, Britain and even more so in the traditional Asian markets. Deflation was a common trait in these economies (Gootenberg 1990). In some silver-rich countries several mints appeared and cut coins of various qualities - some of which reasonably should have ended up in Spain (Irigoin 2009). In circulation along with the francesas, Gresham effects occurred and arguably resulted in deflationary consequences as described by Sardá. Notably the exchange rate of sterling and the French franc remained relatively stable throughout the period 1821-1855 — with exceptional blips in 1847 (Prados de la Escosura 1986, app. 7; Tedde de Lorca 1999, table V-2 and XI-3). Given the state of the banking system, the markets for money and exchange were highly fragmented adding further transaction costs to the already weak integration of the Spanish domestic economy.

Research on the macroeconomic situation of Spain in this period is still a work in progress but evidence from very detailed narratives presents the problems of Spain as being very similar in nature to those of her former colonies. Whereas in some parts of Spanish America inflation was an optimal solution to debt finances in times of war (Bordo and Vegh 2002), it continued being a source in peaceful times and for economies with very different endowments and institutions - such as Bolivia or Buenos Aires as late as the 1850s (Irigoin 2009). The lack of consensus about the form of the state, about the sources of revenues and the liable subjects, and the disassociation between tax collectors and bearers, all contributed to a very low collection rate, a shallow fiscal base and ultimately to insufficient revenues. In a political regime in which representation bore no relation with taxation, governments became insolvent, lacking fiscal capacity or legitimacy (often both), taxation ought to happen without consent.

\section{ANOTHER LEGACY}

Institutionalist interpretations of Latin American long-run development customarily assess her performance against that of the United States. However, the political and fiscal trajectories of the former colonies of Spain and Britain after independence were hardly comparable. As historian Edling 
(2003) rightly explains, the revolution in the British colonies was «in the favour of government», not «against the government» as was precisely the case in the Spanish colonies. This difference makes the comparison of their respective institutional paths quite problematic. Moreover, considering that both Spain and her former colonies were in similar predicaments after independence it is difficult to identify it as a prejudice from the colonial legacy. Under British rule North American colonies were also separate fiscal and political units, but they were financed by a metropolis, which took on their defence and minimal government expenses. Unlike the Spanish settlements, where the church provided most public goods with substantial funding from the royal purse, the British colonies funded public goods such as education with direct taxes raised locally. When the French Indian War in the 1750s and 1760s demanded further revenues - and to the colonies to bear part of the fiscal costs - Parliament met fierce resistance to further (indirect) consumption taxes required from the colonists ${ }^{22}$. This asymmetry between taxation and the representation of the colonies in parliament triggered the American Revolution and tax resistance continued until the 1790s.

The British levied direct taxes on colonial property and faculty as early as 1660 (Fisher 2015) ${ }^{23}$; however, no comparable taxes were charged in the metropolis where direct taxes increased only after 1792. In parliamentary England sources of direct taxation - mainly land - had been in relative decline since the 1690s. For most of the $18^{\text {th }}$ century customs and excise constituted the bulk of her revenues (Ashworth 2003). Apparently, the fiscal burden was low in the British colonies - and certainly much lower than in the metropolis. However, as Zolt (2009, p. 455) shows «representation came at a cost» to independent United States: from 1792 to 1811 the per capita tax take increased ten times from what the empire had charged in 1765-1775. Direct taxes collected by local government did not cease with the revolution and their income represented a substantial part of the revenues available to the new state governments. By 1825, the total tax take of the US government was $\$ 4.33 /$ person of which 54 per cent corresponded to income appropriated by the state and local governments (Zolt 2009, table 1). It jumped to $\$ 8.86$ in 1855 , which meant more than double the 1825 value in real terms ${ }^{24}$. This burden was certainly much higher than the per capita contribution borne by Spanish Americans as seen in Table $4^{25}$.

${ }^{22}$ The Townshend Act followed the (repealed) Stamp Act, the Sugar Act and others and sought to raise revenue in the colonies for self-maintenance. It culminated with the Tea Act of 1773 and protests in Boston.

${ }^{23}$ Faculty taxes were levied on the faculty or earning capacity of persons following certain trades or having certain skills.

${ }^{24}$ According to the US dollar purchasing power www.measuringworth.com/uscompare/reativevalue.php. The annualised inflation rate in the period was -0.45 per cent.

${ }^{25}$ The US dollar and the Spanish American silver peso remained legal tender at par until 1856. 
This growth includes the extraordinary fiscal expansion of the Federalist period. Only in 1787-1789, the Philadelphia Convention incorporated the former colonies into a federal United States transforming the equal representation of states in the Continental Congress for the proportional representation of citizens in the House of Representatives. This political experiment, the Confederation in which Congress took the governing role from the king, had collapsed under the compound of insolvency and currency inflation in 1782-1788 26 (Edling 2014). As part of the Federalist fiscal programme, the federal government assumed the debt of the individual states and paid them at par with new federal public bonds; this significantly relieved the state governments of the cost of the transition to a new political order. In 1790, seventy-four million dollars' worth of domestic and foreign debt - about 30 per cent of $\mathrm{GNP}^{27}$ - were consolidated in long-term interest - bearing bonds which the federal government serviced regularly with revenues from trade taxes. Having been part of the fiscal burden levied by the British, the US government appropriated what had formerly belonged to the empire. The tariff was a prerogative the states surrendered to the federal government by the Impost Acts of 1790. Together with some low excise taxes on alcohol, tobacco and sugar, the tariff thereafter constituted 70-80 per cent of federal income in the period. Customs revenues amounted to $\$ 4.6$ million in 1792 (about 2 per cent of GNP) or $\$ 1.36$ per capita; in nominal terms they doubled by 1800 , tripled by 1805 and then quadrupled by 1820 . By 1850 , the tariff at $\$ 39$ million - or $\$ 1.98$ per capita - still represented 82 per cent of federal revenues (Finances 1870).

What sets the Federalist and Republican programmes apart from the Latin American fiscal reforms - and from the previous disastrous experience of the Confederation - is the extraordinary capacity the federal state had to service the interest and principal of its debt (Wallis 2000). This capacity to tax was not available to governments in Spanish America - nor in Spain - not because of the type of levies, but because governments there could not establish a taxation system that worked. North Americans eventually agreed to shoulder heavier taxes than under British rule (Edling 2003, p. 156). The per capita burden calculated by the tax take of the three levels of government combined had doubled in 1855 from the per capita contribution of 1820, meanwhile population had tripled. (Zolt 2009, p. 458). So even if the United States, like Latin American republics, relied on customs to service the debt, the argument about the colonial fiscal burden in the case of Spanish America needs some closer scrutiny to substantiate it.

26 The Constitutional Convention alienated the rights to coin or print money from the state and gave the federal government the power to coin in 1792. It also changed the representation of the individual states in Congress for the proportional representation of their population.

27 Of the $\$ 74$ million, $\$ 12-\$ 22$ million corresponded to the state's debt. GNP and debt data from Bordo and Vegh (2002). 
Prados de la Escosura (2009) explains the extremely different success of the financial origin of republics in the Americas by the recurrence of deficits. Already weak Latin American governments were further prejudiced by vicious circles of insolvency, debt and inflation. Indeed the problem was the impossibility to raise debt because they were no credible payers ${ }^{28}$. By looking solely at the federal level, however, scholars tend not to see the real size of the fiscal burden borne by the US taxpayer. Considering that the federal burden was half or less than the three levels of government take, it means that there was a significant amount of money still appropriated by local and state treasuries. This income originated in direct taxes and, more importantly, it was spent on education and infrastructure; something which no fiscal district in Spanish America was remotely able to dream of as the overwhelming share of expenses went on war (Centeno 2002).

Spanish American (aspiring) governments in capital cities were charging indirect trade taxes on taxpayers elsewhere; the latter had no vote or say in the spending of these revenues, nor were there channels for redistribution as the transfers that had formerly allowed the co-optation of regional elites even if for marginally productive ventures. Indirect taxation without representation was the means that republican governments had to establish their authority at the centre, and at the top, of the polity in Spanish America. For taxpayers the burden was greater if a government elsewhere controlled the custom house at the port or the tobacco monopoly - as in landlocked capitals such as Bogota, Mexico and Santiago de Chile. Relief from the colonial tax burden was non-existent for the population overall - if it existed it was appropriated by elites in the capital cities who increasingly restricted political representation of territories and individuals. Unsurprisingly fiscal federalism failed. Whereas in the federal United States, some states even invested in banks, turnpike and canal construction through private-public partnerships and taxed profits from banks and insurance companies and capital gains on these stocks (Sylla 1999, p. 266). Thus, some states managed to fund up to 60 per cent of their expenses and participated of the greater fiscal capacity of the federal state, which relieved them from the old debts. The federal government also shared revenues from land sales and taxes on businesses. Furthermore, in New England these revenues were sufficient to enable some reduction or elimination of state property taxes early on.

Scholars have shown the importance of state revenues for the provision of public education in the United States (Go and Lindert 2007); by 1820 the Common School achieved the best literacy rate in the world thanks to income from direct taxes invested in education serving a broad population. There were significant regional variations between states, however.

${ }^{28}$ The Empire of Brazil adds an interesting twist to institutional explanations about the role of limited government and political institutions in providing secure property rights and hence growth (Summerhill 2015). 
Zolt (2009) argues that this explains the different type of taxes chosen to support public education spending, and hence inequality levels within the United States (Lindert 2004; Zolt 2009). Elsewhere, Sokoloff and Zolt (2006, p. 179) have related this to the contemporary extension of the franchise in the United States. They thus explain the different growth performance in South and North America in the provision of education resultant from the legacy of inequality that taxation imposed in each part of the continent. The channel, they argue, was suffrage institutions. Thus, allegedly, North Americans had a less restricted franchise, greater turnout at the ballots and a vigorous primary education funded by direct taxation. Latin Americans, on the other hand, had increasingly more restricted franchise, lower turnout and did not - and could not - invest in education to account for (Curvale and Przeworski 2008). However, it was not until the Fifteenth Amendment to the Constitution in 1870 that all male US citizens were granted the right to vote, and most blacks were still disenfranchised, banned or discriminated at the ballot box until the Voting Rights Act of 1965 made suffrage universal. Ironically, until 1964 five southern states used the payment of poll tax as a requirement to vote, which was repealed by the Twenty-Fourth Amendment - yet eight states have not ratified it to date.

Notwithstanding, Spanish Americans were not originally precluded from voting and had significant means for investing in education at their disposal given their rate of control over colonial treasuries. Furthermore, every early constitutional text included a chapter on public education as a right to the people and a responsibility of the state. However, asymmetries between agents deciding collection and spending of revenues from mainly indirect taxes rendered paltry yields to the treasury. Direct taxation in the United States also proved an advantage for more equal, better educated societies (in some states) because as Zolt (2009, p. 449) points out, "where the median voter has less income than the mean, the median voter will favour income tax regimes under which her share of taxes will be less than their share of government benefit supported by the tax revenue». This theorem may not work if the median voter pays indirect taxes for which, moreover, rates are decided elsewhere and revenues are disinvested from public goods to service debt or eroded by inflation. This was the situation in republican Spanish America, where a substantial provision of public goods was taken care of by private sources like the church and charities and so not perceived as return for taxation. Similarly a number of private goods were provided by public sources which were part and parcel of the "developmentalism» of the colonial state; thus employment, food security and a host of subsidies to private activities were then understood as entitlements ${ }^{29}$. In this case, the median voter would dissociate the identity between revenue and expenditure and

29 The «developmentalist» state in Spanish America is explained in Grafe and Irigoin (2012). It differs substantially from the developmental state conceived by Robinson and Pincus (2015). 
may unreasonably prefer lower taxation to fund lower expenditure given that no real redistributive effects were to be expected.

\section{CONCLUSIONS}

Weakened governments could not tax, without income they could not last and they even had to spend more and more to remain in power. Political instability was rooted in the fiscal fragility of the state and every new constitution faltered as fast as the previous one. Paradoxically in Spanish America, instead of relieving the burden of colonial taxation, independence further weakened the capacities - fiscal, legal and administrative - of the republican state and undermined the political institutions that it organised. Over time - because of inelastic expenses from political turmoil on top of growing demands on future income from debt and prejudices from monetary disorder - all compounded in chronic fiscal deficits and broken governments. Fiscal bases were shallow and shrinking as countries lost import or consumption capacity as a result of exchange rate problems and disintegrating domestic markets. Further, borrowing at shorter terms and higher interest rates led governments such as that of Mexico to real bankruptcy within 30 years (Tenembaun 1986; Irigoin 2009). Other governments with even lower fiscal capacity inflated their debts by monetary expansion such as that of Bolivia, or suffered from the impossibility to execute any monetary policy, such as Spain or Peru until the 1850s. The lack of consensus regarding the form of the state, its fiscal basis and the disassociation between tax collectors and bearers ultimately undermined the capacities of the (any) state. The incidence of regressive taxation on producers (exporters) and consumers originated large redistribution effects, which further aggravated centrifugal tensions.

Without fiscal capacity neither debt service nor tax smoothing was possible for Latin American governments. Lack of fiscal capacity and regressive taxation had persistent implications in the making of the republican state. For instance, the first Mexican constitution of 1824 devised a mechanism to incorporate nineteen formerly separate treasury districts into a federal republic. It was meant to be a compromise between states and ayuntamientos to fund the fiscal reorganisation of the new federation. Replicating Cadiz article 340, the Mexican congress apportioned each state's contribution by a poorly defined combination of population size and consumption, that is, the Contingente. The political bargaining was extremely difficult and returns soon foundered, constituting 24 per cent of federal revenues in 1824 and originated in the same mining regions that had formerly transferred large shares of their revenues to the colonial capital, but without vote or voice (Arroyo 2006). It fell to 10 per cent in the following years and collapsed further to 3 per cent in 1831 when contributions ceased; meanwhile total 
revenues of the federal government nearly halved. Conversely, in the United States when war expenses created extra needs, as in 1812, the federal government could temporarily levy an extraordinary federal property tax on states on the basis of population to great effect. Underpinning the failure of Mexican fiscal federalism - comparable with other experiments in Spanish America - was the protracted conflict regarding the sources of national revenues and the form of the state.

In the process, restrictions to suffrage mounted with wealth and literacy requirements throughout Spanish America; elections evolved into a form of proclamation of every new government rather than an actually organised and fair competition for power. The early open contest for the popular will soon ran out of funds; henceforth governments traded entitlements for support. Political strife moved from the ballots to the battleground, and further to the streets. Suffrage became denaturalized With ad hoc elections representative democracy in Spanish America moved one step towards what scholars calls a «Delegative Democracy» (O'Donnell 1994) as opposed to a representative one. In this environment there were no effective means to fund governance and far less to deliver the constitutional promises of public education. As governments resorted to even more perverse means to defray expenses, such as liquidating massive tracts of public land when relative price was rising from greater labour ratios and higher prices for land-intensive commodities from globalisation, governments only accelerated already high levels of inequality. Thus, in $19^{\text {th }}$ century Spanish America - and in Spain inequality is the by-product of an institutional legacy other than colonial status. Elites, on the other hand, managed to deter both greater fiscal extraction from governments and institutional demands for political redistribution from fellow citizens. Fiscal reforms were ineffectual or null and representation was increasingly more restrictive. Low taxation was in their interest as they could acquire public goods privately. For the masses, the expectation - and experience - of public provision of private goods put governments in the position of continuous patronage in order to buy out their legitimacy, irrespective of the financial means available. Insolvency, inflation and instability are long-term features in these countries, together with regressive fiscal policies. Placing the fiscal burden on others or in the future brought elites and masses together in a perverse combination of low taxation and representation. This intertemporal trap of the peculiar Latin American political and macroeconomic (dis)equilibrium seems to be indeed more a legacy of the $19^{\text {th }}$ century.

\section{REFERENCES}

Abendroth, H. (1990): «Finanzas públicas y estructura social en Bolivia, 1825-1872. Staatsfinanzen und Sozialstruktur Boliviens 1825-1872», Magister-Hausarbeit am Fachbereich Geschichtswissenschaften. History, Berlin, Freien Universitat. 
Aguilar Rivera, J. (ed.) (2010): Las Elecciones y el Gobierno Representativo en México (1810-1910). México: CFE-IFE.

Alexander Rodríguez, L. (1992): The Search for Public Policy: Regional Politics and Government Finances in Ecuador, 1830-1940. Berkeley, CA: University of California Press.

Amaral, S. (1993): «Del Mercantilismo a la Libertad. Las Consecuencias Económicas de la Independencia Argentina», in L. Prados de la Escosura, and S. Amaral (eds), La Independencia Americana: Consecuencias Económicas. Madrid: Alianza, pp. 201-218.

Anna, T. (1974): «Economic Causes of San Martin’s Failure in Lima». Hispanic American Historical Review 54 (4), 657-681.

Annino, A. (ed.) (1995): Historia de las Elecciones en Iberoamérica, Siglo XIX. Buenos Aires: FCE.

Arroyo, I. (2006): «México: Proporcionalidad en el Contingente y Formas de Gobierno, 1824-1857», in L. Jáuregui (ed.), De Riqueza e Inequidad. El Problema de las Contribuciones Directas en América Latina, Siglo XIX. México: Instituto Mora, pp. 149-183.

Ashworth, W. (2003): Customs and Excise: Trade, Production and Consumption in England, 1640-1845. Oxford: Oxford University Press.

Benson, N. (1946): "The Contested Mexican Election of 1812». Hispanic American Historical Review 26 (3), 336-350.

Bordo, M., and Cortes Conde, R. (eds) (2001): Transferring Wealth and Power from the Old to the New World. Monetary and Fiscal Institutions in the 17th Through the 19th Centuries. New York: Cambridge University Press.

Bordo, M., and VEGH, C. (2002): «What if Alexander Hamilton had Been Argentinean? A Comparison of the Early Monetary Experiences of Argentina and the United States». Journal of Monetary Economics 49 (3), 459-494.

Burgin, M. (1947): The Economic Aspects of Argentine Federalism, 1820-1850. Cambridge: Harvard University Press.

Bushnell, D. (1953/1970): The Santander Regime in Gran Colombia. Westport, CT: Greenwood Press.

Canga Argüelles, J. (1833): Diccionario de Hacienda con aplicación a España. Madrid: Imprenta de Calero y Portacarrero.

Caplan, K. (2003): «The Legal Revolution in Town Politics: Oaxaca and Yucatán, 1812-1825». Hispanic American Historical Review 83 (2), 255-293.

Carreras, A. (ed.) (2005): Estadísticas Históricas de España Siglos XIX-XX. Bilbao: Fundacion BBVA.

Centeno, M. (2002): Blood and Debt. War and the Nation State in Latin America. University Park, PA: Pennsylvania University Press.

Challú, A., and Gómez Galvarriato, A. (2015): "Mexico's Real Wages in the Age of the Great Divergence, 1730-1930». Revista de Historia Económica/Journal of Iberian Latin American Economic History 33 (1), 83-122.

Contsworth, J. (1978): «Obstacles to Economic Growth in Nineteenth Century Mexico». American Historical Review 83 (1), 80-100.

Contsworth, J. (1993): «La Independencia Latinoamericana: Hipótesis Sobre sus Costes y Beneficios», in L. Prados de la Escosura, and S. Amaral (eds), La Independencia Americana: Consecuencias Económicas. Madrid: Alianza, pp. 17-30.

COATsworth, J. (1998): "Economic and Institutional Trajectories in Latin America», in J. Coatsworth, and A. M. Taylor (eds), Latin American and the World Economic Since 1800. Cambridge, MA: Harvard University Press, pp. 23-54. 
Coatsworth, J., and Williamson, J. (2004): «Always Protectionist? Latin American Tariffs from Independence to Great Depression». Journal of Latin American Studies 36 (2), 205-232.

Сомín, F. (1988): Hacienda y Economía en la España Contemporánea, 1800-1936. Madrid: Ministerio de Econonomía y Hacienda.

Contreras, C. (1999): «La minería hispanoamericana después de la independencia. Estudio comparativo de Bolivia, Chile, México y Perú», in M. Bornemann (ed.), Dos décadas de investigación en historia económica comparada en América Latina, homenaje a Carlos S. Assadourian. México: Instituto Mora, pp. 255-283.

Contreras, C. (2006): "Las Contribuciones Directas en la Formación del Perú Republicano», in L. Jáuregui (ed.), De Riqueza e Inequidad. El Problema de las Contribuciones Directas en América Latina, siglo XIX. México: Instituto Mora, pp. 123-149.

Curvale, C., and Przeworski, A. (2008): «Does Politics Explain the Economic Gap Between the United States and Latin America», in F. Fukuyama (ed.), Falling Behind: Explaining the Development Gap Between Latin America and the United States. Oxford and New York: Oxford University Press, pp. 99-133.

Deans Smith, S. (1992): Bureaucrats, Planters and Workers. The Making of the Tobacco Monopoly in Bourbon Mexico. Austin, TX: University of Texas Press.

Deas, M. (1996): "The Role of the Church, the Army and the Police in Colombian Elections, c. 1850-1930», in E. Posada-Carbó (ed.), Elections Before Democracy: The History of Elections in Europe and Latin America. London: ILAS-Palgrave, pp. 163-180.

Dye, A (2006): «The Institutional Framework», in V. Bulmer Thomas, J. Coatsworth, and R. Cortes Conde (eds), The Cambridge Economic History of Latin America. vol. II New York: Cambridge University Press, pp. 169-207.

Eastman, S., and Sobrevilla Perea, N. (2015): The Rise of Constitutional Government in the Iberian Atlantic World; the Impact of the Cádiz Constitution of 1812. Tuscaloosa: University of Alabama Press.

Echeverri, M. (2015): "Race, Citizenship and the Cadiz Constitution in Popayan (New Granada)», in S. Eastman, and N. Sobrevilla Perea (eds), The Rise of Constitutional Government in the Iberian Atlantic World: The impact of the Cadiz Constitution of 1812. Tuscaloosa: University of Alabama Press, pp. 91-110.

EdLING, M. (2003): A Revolution in Favour of Government. Origins of the US Constitution and the Makings of the American State. New York: Oxford University Press.

Eduing, M. (2014): A Hercules in the Cradle. War, Money and the American State, 17831867. Chicago, IL: Chicago University Press.

Finances, Secretary of the Treasury. (1870): Annual Report of the Secretary of the Treasury on the State of the Finances for the Year 1870. Washington, DC: Government Printing Office, XXVI-XXVIX.

Fisher, G. (2015): «History of Property Taxes in the US». Available at http://Eh.net/ encyclopedia/history-of-property-taxes-in-the-united-states

FontanA, J. (1987): La Quiebra de la Monarquía Absoluta (1814-1820). Barcelona: Ariel.

FowLER, W. (2010): «Entre la Legalidad y la Legitimidad: Elecciones, Pronunciamientos y la Voluntad General de la Nación, 1821-1857», in J. Aguilar Rivera (ed.), Las Elecciones y el Gobierno Representativo. México: CFE, pp. 95-122.

García Orozco, A. (ed.) (1978): Legislación Electoral Mexicana 1812-1977. México: Comisión Federal Electoral.

Go, S., and Lindert, P. (2007): «The Curious Dawn of American Public Schools». NBER Working Papers. Available at http://papers.nber.org/papers/w13335 
Gootenberg, P. (1990): «Carneros y Chuno: Price Levels in Nineteenth-Century Peru». The Hispanic American Historical Review 70 (1), 1-56.

Grafe, R., and Irigoin, A. (2006): "The Spanish Empire and its Legacy: Fiscal Redistribution and Political Conflict in Colonial and Post-colonial Spanish America». Journal of Global History 1 (2), 241-267.

Grafe, R., and Irigoin, A. (2012): «A Stakeholder Empire: The Political Economy of Spanish Imperial Rule in America». Economic History Review 65 (2), 609-651.

Grieco, V. (2014): The Politics of Giving in the Vicerroyalty of Rio de la Plata. Donors, Lenders, Subjects and Citizens. Albuquerque: University of New Mexico Press.

Guerra, F. (1994): "The Spanish American Tradition of Representation and its European Roots». Journal of Latin American Studies 26 (1), 1-35.

Halperin Donghi, T. (1979): Revolución y Guerra. Formación de una élite dirigente en la Argentina criolla. Mexico: Siglo XXI.

Hamilton, E. J. (1929): «Imports of Gold and Silver into Spain, 1503-1660». Quarterly Journal of Economics 43 (3), 436-472.

Irigoin, A., and Grafe, R. (2008): «Bargaining for Absolutism: A Spanish Path to Nation State and Empire Building». Hispanic American Historical Review 88 (2), 173-209.

IRIGoIN, A. (2000): «Inconvertible Paper Money, Inflation and Economic Performance in Nineteenth Century Argentina». Journal of Latin American Studies 32 (2), 333-359.

IrIGoIN, A. (2009): «Gresham on Horseback. The Monetary Roots of Spanish America Political Fragmentation in the Nineteenth Century». Economic History Review 62 (3), 551-575.

Jacobsen, N. (1989): «Taxation in Early Republican Peru, 1821-1851: Policy Making Between Reform and Tradition», in R. Liehr (ed.), América Latina en la época de Simón Bolivar. La formación de las economías nacionales y los intereses económicos europeos, 1800-1850. Berlin: Colloquium Verlag, pp. 311-340.

JÁuregui, L. (2010): «México: la Experiencia de las Participaciones Federales en el Siglo XIX». Illes Imperis 13, 137-157.

Johnson, L. (1979): «Estimaciones de la Población de Buenos Aires en 1744, 1778 y 1810». Desarrollo Económico 19 (73), 107-119.

Kalmanovitz, S. (2006): "El PIB de la Nueva Granada en 1800: Auge Colonial, Estancamiento Republicano». Revista de Economia Institutional 8 (15), 161-183.

KLeIN, H. S. (1993): Hacienda and Ayllus. Rural Society in the Bolivian Andes in the Eighteen and Nineteenth Centuries. Stanford, CA: Stanford University Press.

Lindert, P. (2004): Growing Public: Social Spending and Economic Growth Since the Eighteenth Century. Cambridge: Cambridge University Press.

Llopis, E., and MARICHAL, C. (2009): Latinoamérica y España tras la independencia, 1821-1870. Un crecimiento económico nada excepcional. Madrid: Marcial Pons-Instituto Mora.

Lofstrom, W. (1970): «Attempted Economic Reform and Innovation in Bolivia Under Jose Antonio Sucre, 1825-1828». Hispanic American Historical Review 50 (2), 279-295.

LÓpez Morell, M. (2013): The House of Rothschild in Spain, 1812-1941. Burlington, VT: Ashgate.

Marichal, C. (1989): A Century of Debt Crises in Latin América: From Independence to the Great Depression, 1820-1930. Princeton, NJ: Princeton University Press.

MarichaL, C. (2008): Bankruptcy of Empire: Mexican Silver and the Wars Between Spain, Britain and France, 1760-1810. Cambridge: Cambridge University Press.

Marichal, C., and Grafenstein, J. V. (2012): «El secreto del imperio español: Los situados coloniales en el siglo XVIII». Mexico City: Colegio de México-Instituto Mora.

Martín Aceña, P. (1981): «España y el Patrón oro (1880-1913)». Hacienda Pública Española 69, 267-290. 
Mitre, A. (1986): El Monedero de los Andes. Región Económica y Moneda Boliviana en el Siglo XIX. La Paz: HisBol.

Nogués-Marco, P. (2005): «Análisis de la Deflación Española de la Primera Mitad del siglo XIX: Una Comparación Internacional». Revista de Historia Económica 23 (2), 371-405.

O'Donnell, G. (1994): «Delegative Democracy?». Journal of Democracy 5 (1), 55-69.

Pérez Herrero, P. (2010): «El tratamiento de la fiscalidad en las constituciones del mundo atlántico (1787-1830)», in P. Pérez Herrero, and I. Simón Ruiz (eds), El liberalismo, la creación de la ciudadanía y los estados nacionales occidentales en el espacio Atlántico (1787-1880). Bucaramanga: Universidad de Alcalá-Univ. Industrial de Santander, pp. 163-258.

Platt, D. C. (1983): «Las Finanzas Extranjeras en España, 1820-1870». Revista de Historia Económica 1 (1), 121-150.

Platt, T. (1982): Estado Boliviano y Ayllu Andino: Tierra y Tributo en el Norte de Potosí. La Paz: Instituto de Estudios Peruanos.

Posada-Carbó, E. (ed.) (1996): Elections Before Democracy: The History of Elections in Europe and Latin America. New York: St Martins.

Prados de la Escosura, L. (1986): «Una Serie Anual del Comercio Exterior (1821-1913)». Revista de Historia Económica 4 (1), 103-150.

Prados de la Escosura, L. (1993): "La Pérdida del Imperio y sus Consecuencias Económicas», in L. Prados de la Escosura, and S. Amaral (eds), La Independencia Americana: Consecuencias Económicas. Madrid: Alianza, pp. 253-300.

Prados de la Escosura, L. (2009): «Lost Decades? Economic Performance in PostIndependence Latin America». Journal of Latin American Studies 41 (2), 279-307.

QuiJada, M. (2008): «From Spain to New Spain: Revisiting the Potestas Populis in Hispanic Political Thought». Mexican Studies/Estudios Mexicanos 24 (2), 185-219.

Robinson, J., and Pincus, S. (2013): «Wars and State Making Reconsidered: The Rise of the Interventionist State». Paper presented at the Harvard Business School's Business, Government and the International Economy, HBS Harvard, Cambridge, MA. Available at www.hbs.edu/faculty/conferences/2013-bgie/documents

Roca, J. (2007): Ni con Lima ni con Buenos Aires. La formación de un Estado Nacional en Charcas. Lima: IDEA Plural.

Sánchez-Albornoz, N. (1978): Indios y Tributos en el Alto Perú. Lima: Instituto de Estudios Peruanos.

Sánchez SantiRó, E. (2009): Las Alcabalas Mexicanas, 1821-1857. México: Instituto Mora.

SARDÁ, J. (1947): «Spanish Prices in the Nineteenth Century». The Quarterly Journal of Economics 62 (1), 143-159.

SARDÁ, J. (1948): La Politica Monetaria y las Fluctuaciones de la Economía Española en el Siglo XIX. Madrid: Instituto de Economia Sancho de Moncada.

SARTORIOus, D. (2015): "Of Exceptions and Afterlife. The Long History of the 1812 Constitution in Cuba», in S. Eastman, and N. Sobrevilla Perea (eds), The Rise of Constitutional Government in the Iberian Atlantic World. Tuscaloosa: University of Alabama Press, pp. 150-176.

Serrano, J. A. (2010): «Reformas Fiscales a Ambos Lados del Atlántico: México (18361842) y España (1845-1854)», in P. Pérez Herrero, and I. Simón Ruiz (eds), El Liberalismo, la Creación de la Ciudadanía y los Estados Nacionales Occidentales en el Espacio Atlántico (1787-1880). Bucaramanca: Universidad de Alcalá-Univ. Industrial de Santander, pp. 321-362.

Serrano Ortega, J. (2007): Igualdad, Uniformidad, Proporcionalidad. Contribuciones Directas y Reformas Fiscales en México, 1810-1846. México: Instituto Mora. 
Sokoloff, K., and Engerman, S. (2000): «Institutions, Factor Endowments and Paths of Development in the New World». Journal of Economic Perspectives 14 (3), 217-232.

SoKoloff, K., and Zolt, E. (2006): «Inequality and Taxation: Evidence from the Americas on How Inequality May Influence Tax Institutions». Tax Law Review 59, 167-241.

Stevens, D. (1991): Origins of Instability in Early Republican Mexico. Durhan: Duke University Press.

Summerhill, W. (2008): «Fiscal Bargains, Political Institutions, and Economic Performance». Hispanic American Historical Review 88 (2), 219-232.

Summerhill, W. (2015): Inglorious Revolution: Political Institutions, Sovereign Debt, and Financial Underdevelopment in Imperial Brazil. New Haven, CT: Yale University Press.

Sylla, R. (1999): «Shaping the US Financial System 1690-1913: The Dominant Role of Public Finance», in R. Sylla, R. Tilly, and G. Tortella (eds), The State, the Financial System and Economic Modernization. New York: Cambridge University Press, pp. 249-270.

TedDe de Lorca, P. (1999): El Banco de San Fernando (1829-1856). Madrid: Alianza.

Tedde de Lorca, P., and Marichal, C. (1994): La formación de los Bancos Centrales en España y América Latina (siglos XIX y XX). vol 1 Madrid: España y México, Banco de España-Servicios de Estudio.

Tenenbaum, B. (1986): The Politics of Penury: Debts and Taxes in Mexico, 1821-1856. Austin, TX: University of Texas Press.

Tepaske, J. J., and Klein, H. S. (1982): The Royal Treasuries of the Spanish Empire in America. Durham, NC: Duke University Press.

Ternavasio, M. (2015): «The Impact of Spanish Constitutionalism in the Rio de la Plata», in S. Eastman, and N. Sobrevilla Perea (eds), The Rise of Constitutional Government in the Iberian Atlantic World. Tuscaloosa: University of Alabama Press, pp. 133-149.

Torres Medina, J. (1998): «La Ronda de los Monederos Falsos. Falsificadores de moneda de cobre (1835-1842)», in B. V. Covarrubias (ed.), La Moneda en México. México: Instituto Mora, pp. 107-130.

Urquijo Goitia, J. R. (2015): «Diccionario Biográfico de los ministros españoles en la edad contemporánea (1808-2000)». Available at www.ih.csic.es/lineas/jurg/diccionario/ index_dic.htm

WaLlis, J. (2000): «American Government Finance in the Long Run: 1790-1900». Journal of Economic Perspectives 14 (1), 61-82.

Warren, R. (1996): «Elections and Popular Political Participation in Mexico, 18081836», in V. Peloso, and B. Tenenbaum (eds), Liberals, Politics and Power. Athens: University of Georgia Press, pp. 30-59.

Yun Casalilla, B., O’Brien P., and Comin Comin, F. (2012): The Rise of Fiscal States: A Global History, 1500-1914. Cambridge: Cambridge University Press.

Zolt, E. M. (2009): «Inequality, Collective Action, and Taxing and Spending Patterns of State and Local Governments». Tax Law Review 62, 445-504. 